\title{
石灰石鉱山における穿孔機の適用性の評価
}

\author{
島田 英 樹 ${ }^{1}$ 江 口 元 $^{2}$ 松井紀 久 男 $^{3}$
}

\section{Estimation of Applicability of Drilling Machine in Limestone Quarry}

by Hideki SHIMADA ${ }^{1}$, Gen EGUCHI ${ }^{2}$ and Kikuo MATSUI ${ }^{1}$

1. Faculty of Engineering, Kyushu University, Higashi-ku, Fukuoka 812-81

2. Kajima Corporation Ltd.

\begin{abstract}
In Japanese open pit limestone quarries, the drill and blast method using the bench cut system is employed. Since the success of drilling machine is more sensitive, its application should be made after proper evaluation of geological conditions and rock characteristics in order to predict the machine performance and bit consumption and so on. Geological conditions have a significant effect on the performance of drilling machine. Unconfined compressive strength or uncofined tensile strength of intact rock which is used as an index for criterion or prediction is not good because the fragmentation mechanism is not considered well. It is more important to consider the consumed energy value in fragmentation such as the rock impact hardness number $(R I H N)$ than the strength failure value such as the unconfined compresive strength or the unconfined tensile strength for criterion or prediction of machine perform-

From these points of view, this paper discusses the predicting method of the drilling rate and the selecting method of the drilling machine by using the rock impact hardness number, RIHN.

KEY WORDS : Limestone Quarry, Drilling Machine, Rock Impact Hardness Number (RIHN), Drilling Rate, Applicability
\end{abstract} ance.

\section{1. 緹}

わが国の石灰石鉱山では，主にベンチカット穿孔・発破工法に よる採掘が行われており, 各種作業の効率, 経済性, 安全性のみ ならず，作業環境や人的問題を考慮して，さらに一層の機械化， 自動化, 省力化が要求されている。そこで作業の合理化や生産コ ストの削減を図るために, 高能率の大型穿孔機が多数導入され, 穿孔能率は飛躍的に増大している。一方，ここ数年鉱山周辺の都 市化が進み, 発破振動や騒音, 飛石などの環境・保安問題で発破 による採掘作業が大きく制限されつつある現状から，これらの問 題に対処するために無発破による破砕工法等の研究開発 ${ }^{112)}$ あ試 みられている。しかし，現時点では無発破採掘システムが十分に 確立されていないことやこれの導入に伴う多大なコスト等を総合 的に考慮すると，この工法を即採用できるといった状況ではない ため, 今後も現行の穿孔・発破による採掘がかなりの割合を占め ると思われる。

穿孔・発破採掘の方法としては, 穿孔, 装薬, 発破の順に行わ れ，この中でも穿孔作業が中心的な位置を占めている。したがっ て作業効率や生産性を向上させるためには, 穿孔機導入の際, 能

* 1994 年 8 月 29 日受付 11 月 28 日受理 資源・素材学会平成 6 年度春季大 会 (1994 年 3 月) にて一部発表

1. 正会員 工博 九州大学助手 工学部資源工学科

2. 鹿島建設(株)

3. 正会員 工博 九州大学教授 工学部資源工学科

〔著者連絡先〕 FAX 092-641-4603 (九大・資源)

キーワード：石灰石鉱山，穿孔機，岩石衝撃硬度数 $(R I H N)$, 穿孔速度, 適用 性
力を十分発揮する機種の選択, すなわち穿孔機の適用性を評価, 把握する必要がある。穿孔機の導入を決定づける要因として, 現 場の地質状態や地山岩石のインタクトな状態における力学特性, 導入が予定されている機械の特性等を挙げることができる。しか し，これらを総括的に考慮した精度の高い穿孔能率の予測や穿孔 機の機種の選定をあ含めた穿孔機の適用性についての汎用的な指 針が未だ十分に得られていないのが実状である。穿孔の原理とし ては, ビットに衝撃を与え, 岩石を打撃することにより穿孔が行 われる打撃式穿孔, ビットに押し付け力を与えた回転により穿孔 が行われる回転式穿孔およびビットに衝撃力と回転力を与えるこ とにより穿孔が行われる回転一打撃式穿孔の 3 種類があり, いず れの穿孔方式でも対象岩石に外力を与え, 新しい自由面の形成に エネルギーが費やされることにより穿孔破砕が行われる。したがっ て, 穿孔機の適用性を評価するためには, 穿孔機を用いる際の石 灰石の破砕しやすさの程度すなわち穿孔性に影響を及ぼす要因を 把握し，穿孔能率や穿孔速度を予測する必要がある。

筆者らは既に岩石の破砕特性あるいは掘削破砕効率を定量的に 評価できるインデックスとして, 衝撃破砕試験より得られる RIHN (岩石衝撃硬度数) が有用であることを報告した ${ }^{3)}$ 。また, RIHN が岩石の掘削破砕効率と密接に関連する穿孔性をむ定量 的に評価できるインデックスとなり得ることも明確にした ${ }^{4)}$ 。そ こで本論文では, 穿孔機の適用性を評価するために, まず石灰石 の破碎性, 平均粒径等が穿孔性によ゙のように影響を及ぼすのかに ついて検討し, 次に岩石の破砕性を定量的に評価できる RIHN を用いた穿孔能率や穿孔速度の予測式の導出手法について言及す る。そして最後に，穿孔機の適用性評価の指針について述べる。 


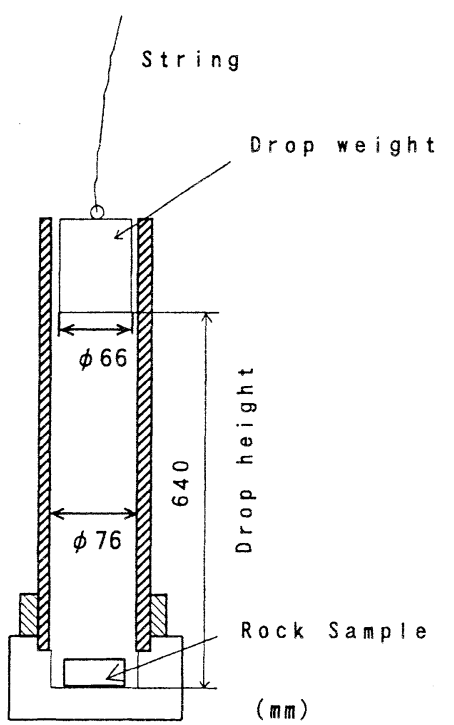

Fig. 1 Apparatus of the impact hardness test.

\section{2. 室内試験, 供試岩石および現場実績データ}

今回用いた衝擊破砕試験装置はFig. 1 に示すように, 岩石供 試体を入れる円筒容器の直径が $76 \mathrm{~mm}$, 落下させる重錘は質量 $2.4 \mathrm{~kg}$, 直径 $66 \mathrm{~mm}$ であり, Protodyakonov 試験装置とほと んど同じである。衝撃破砕試験の試験手順は既報 ${ }^{3)}$ で述べたので ここでは省略する。

試験に供した試料は 9 産地の石灰石であり，このほか比較のた めに大理石, 花崗岩, 安山岩および砂岩を用いた。Table 1 にこ れらの力学的性質および RIHN を示す。

岩石の穿孔性を求めるための穿孔試験には, Fig. 2 に示すよ うにストローク $200 \mathrm{~mm}$, 回転数 $260 \mathrm{rpm}$ で打撃数が每分 2,100 回の能力を有する回転一打撃式穿孔試験装置を用いた。供試体は, 岩石試料下部をセメントにより固定したあのであり，その寸法は $30 \mathrm{~cm} \times 30 \mathrm{~cm} \times 20 \mathrm{~cm}$ である。なお，ビットは直径 $26 \mathrm{~mm}$ のボタンビットを使用し，15，20，25 および $30 \mathrm{kgf} の 4$ 種類の 押し付け力で試験を行い, 各押し付け力による穿孔速度を測定し た。

次に，供試岩石の平均粒径を測定するために，薄片を作製し偏 光顕微鏡を用いて観察した。薄片の作製は, 岩石試料からロック コアリングドリルで直径 $25 \mathrm{~mm}$ のコアをくり抜き, 湿式カッター で厚さ約 $5 \mathrm{~mm}$ に切断し, その後岩石試料中の結晶粒子を偏光 顕微鏡で観察できる厚さ $(0.03 \sim 0.05 \mathrm{~mm})$ まで研摩した。そし て, 結晶粒子の平均粒径 $d(\mathrm{~mm})$ は, 偏光顕微鏡で薄片を観察 しながら，あらかじめ準備した測線を横切る結晶粒子の長さの総 和 $\Sigma L$ 之，その測線を横切る結晶粒子数 $\Sigma n$ を測定して次式によ り求めた。

$$
d=\frac{\sum L}{\sum n}
$$

なお，測線の全長は $62.5 \mathrm{~mm}$ である。Table 2 に試験に供した 石灰石および大理石の平均粒径を示す。

さらに, 害績データとしては, 穿孔ビット径 $B d(\mathrm{~mm})$, 純穿 孔速度 $P R_{n}(\mathrm{~m} / \mathrm{h})$, 総穿孔速度 $P R_{g}(\mathrm{~m} / \mathrm{h})$, 起砕量 $P(\mathrm{t} /$ hole）および起砕能率 $D P_{\mathrm{g}}(\mathrm{t} / \mathrm{h})$ である。これらのパラメータ は下式により求めた。

$$
P R_{n}=\frac{L}{T_{1}}
$$

Table 1 Mechanical properties and the RIHN of the rocks.

\begin{tabular}{l|ccccc}
\hline \multicolumn{1}{c|}{ Rock type } & $\begin{array}{c}S_{c} \\
\left(\mathrm{kgf} / \mathrm{cm}^{2}\right)\end{array}$ & $\begin{array}{c}E_{50} \\
\left(\times 10^{4} \mathrm{kgf} / \mathrm{cm}^{2}\right)\end{array}$ & $\begin{array}{c}S_{t} \\
\left(\mathrm{kgf} / \mathrm{cm}^{2}\right)\end{array}$ & $\begin{array}{c}H_{s} \\
(-)\end{array}$ & $\begin{array}{c}R I H N \\
(-)\end{array}$ \\
\hline sandstone & 650 & 5.5 & 44 & 40 & 9 \\
granite & 1,500 & 14.1 & 83 & 80 & 30 \\
andesite & 880 & 10.1 & 78 & 51 & 25 \\
marble & 500 & 7.7 & 32 & 38 & 10 \\
limestone (A) & 620 & 11.2 & 55 & 48 & 44 \\
limestone (B) & 1,050 & 13.7 & 62 & 45 & 37 \\
limestone (C) & 270 & 5.7 & 28 & 39 & 17 \\
limestone (D) & 1,290 & 14.0 & 81 & 48 & 50 \\
limestone (E) & 1,090 & 13.4 & 56 & 51 & 43 \\
limestone (F) & 800 & 11.7 & 65 & 46 & 46 \\
limestone (G) & 860 & 11.7 & 70 & 46 & 46 \\
limestone (H) & 920 & 13.2 & 65 & 50 & 40 \\
limestone (I) & 670 & 13.2 & 49 & 43 & 10 \\
\hline
\end{tabular}

$S_{c}$ : Unconfined Compressive Strength, $E_{50}:$ Tangent Young's Modulus at $50 \%$ of Unconfined Compressive Strength, $S_{t}$ : Tensile Strength from Brazilian Test, $H_{s}$ : Shore Hardness, RIHN : Rock Impact Hardness Number

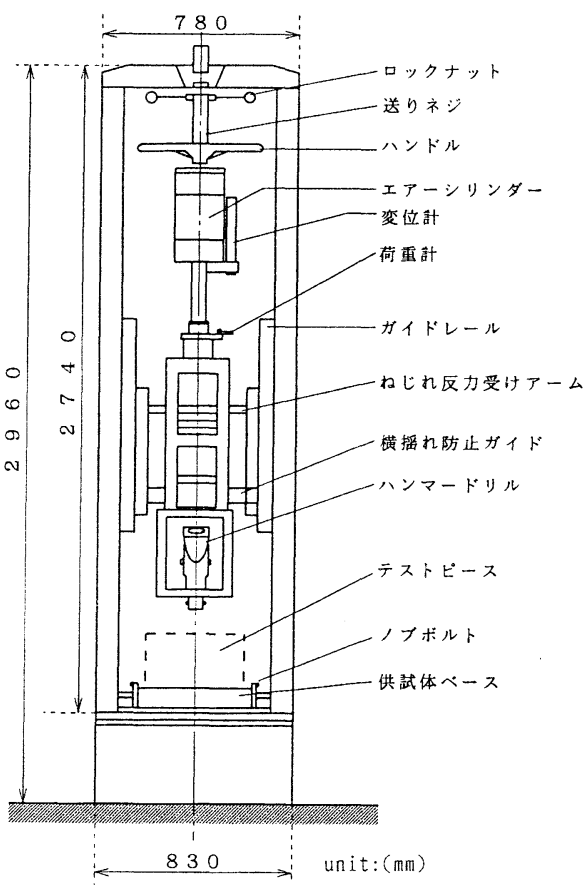

Fig. 2 Apparatus of the drilling test.

Table 2 Grain size of limestones and marble.

\begin{tabular}{l|c}
\hline Rock type & $d\left(\times 10^{-2} \mathrm{~mm}\right)$ \\
\hline limestone (A) & 6.8 \\
limestone (B) & 1.8 \\
limestone (C) & 422.0 \\
limestone (D) & 6.2 \\
limestone (E) & 2.3 \\
limestone (F) & 1.1 \\
limestone (G) & 1.0 \\
limestone (H) & 8.0 \\
limestone ( I) & 45.2 \\
marble & 273.9 \\
\hline
\end{tabular}

$$
\begin{aligned}
& P R_{g}=\frac{L}{T_{1}+T_{2}} \\
& P=\rho \cdot H \cdot W \cdot S \\
& D P_{g}=P \cdot P R_{g} / h
\end{aligned}
$$

ここで, $L$ は総穿孔長 $(\mathrm{m}), \rho$ は密度 $\left(\mathrm{kg} / \mathrm{m}^{3}\right), H$ はベンチ 高さ $(\mathrm{m}), W$ は最小抵抗線 $(\mathrm{m}), S$ は孔間隔 $(\mathrm{m}), h$ は 1 孔 
当たりの穿孔長 $(\mathrm{m} / \mathrm{hole})$ である。また, $T_{1}$ および $T_{2}$ はそれ ぞれ穿孔に要した時間, 穿孔機の移動やロッドの継ぎたし等に要 した時間である。ただし，これらのパラメー夕は各石灰石鉱山で 実際に用いられている発破規格より算出した。また, 石灰石の密 度は $\rho=2.7 \times 10^{3} \mathrm{~kg} / \mathrm{m}^{3}$ 一定とした。

\section{3. 穿孔に影帮を及ばす要因について}

\section{3 ・ 1 押し付け力および RIHN と穿孔速度の関係}

まず，穿孔試験を行った結果得られた代表的な岩種に対する押 し付け力と穿孔速度 $P R$ の関係を Fig. 3 および Fig. 4 に示す。 これらの図より，まず穿孔速度は押し付け力ととむに増大するが， 砂岩では押し付け力が $20 \mathrm{kgf}$ あたりで，石灰石では $25 \mathrm{kgf}$ あた りで穿孔速度の増加率が小さくなり,さらに押し付け力を増大さ せてあ, 穿孔速度は増大せずほぼ一定の值をとる傾向にあること が分かる。これは，押し付け力を増大させてゆくと，岩石内部に より多くの亀裂が発生し, 穿孔破砕によって生じる繰り粉の除去 能力を越えてしまい, 結果的に穿孔速度が増大しないものと考え られている。このような状態に至ると, 穿孔ビットの岩石への食 い込みによる穿孔の停止，あるいは穿孔ビットの破損や，ビット に作用する摩擦力の増大によるビットの摩耗量の増加, あるいは ビットに発生する熱によるビットの疲労や微小亀裂の発生により ビット寿命の著しい低下をむたらすと言われている。したがって, 最適な押し付け力を知ることは, 良い穿孔破䂶効率を得る上で極 めて重要であると考える。

次に, 石灰石の破砕性と穿孔速度の関係について検討する。 Fig. 5 に 15 および $20 \mathrm{kgf}$ の押し付け力を作用させた場合の石灰 石および大理石の $R I H N$ と穿孔速度 $P R$ の関係を示すが，この 図より $R I H N$ と穿孔速度の間には負の相関があり, 岩石の破砕

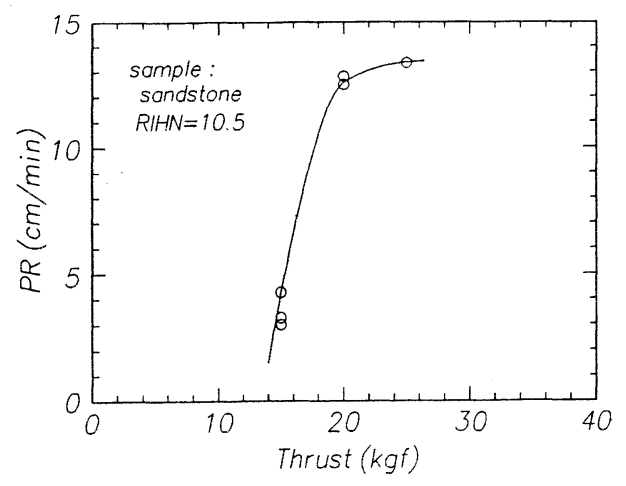

Fig. 3 Relation between the thrust and the drilling rate, $P R$ for sandstone.

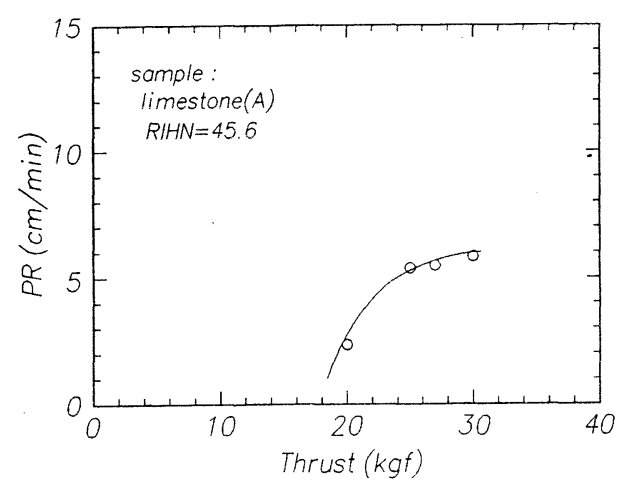

Fig. 4 Relation between the thrust and the drilling rate, $P R$ for limestone.

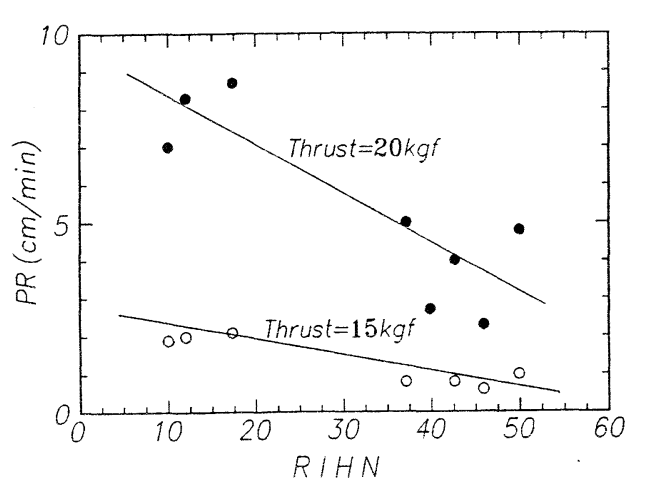

Fig. 5 Relation between the $R I H N$ and the drilling rate, $P R$.

性が大きいほど，すなわち RIHN が小さいほど穿孔速度が大き くなることが認められる。このことから, 石灰石, 大理石の場合, 同一の押し付け力であれば，破砕しやすい岩石の方が大きな穿孔 速度を得ることができると考えられ，穿孔速度は石灰石が本来有 する破砕性に影響されることが分かる。

\section{$3 \cdot 2$ 平均粒径亡穿孔速度および能率の関係}

穿孔速度や能率は，基本的には先述の破砕性はもち万ん，穿孔 の対象となる岩石の組織, 構造等の岩石学的特性値や岩盤特性值 である亀裂の分布状態等にむ大きく依存していると考えられる。 そこで, 石灰石の穿孔性に影響を及ぼすすうひとつの要因として, 石灰石の平均粒径を取り上げる。石灰石は化学的にはほぼ同じ組 成であるにあかかわらず，前掲 Table 2 に示すように構成鉱物 の粒径は産地により大きく異なり, 今回試験に用いた石灰石の平 均粒径の差異は最大で 400 倍以上にもなる。Fig. 6 に平均粒径 $d$ 之穿孔速度 $P R$ の関係を示す。この図より, 平均粒径 $d$ と穿孔

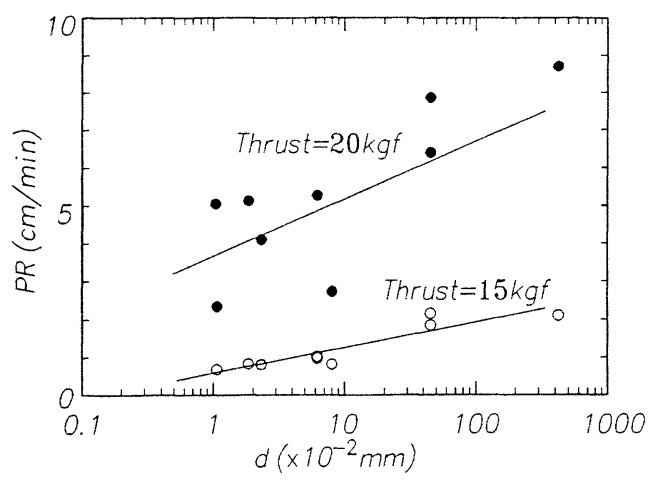

Fig. 6 Relation between the grain size, $d$ and the drilling rate, $P R$.

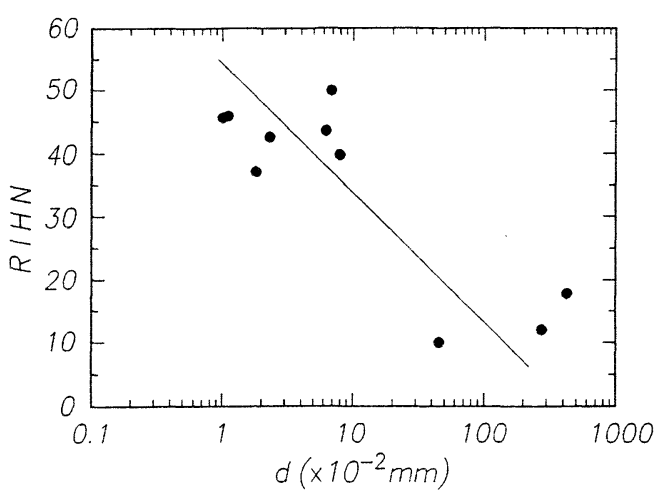

Fig. 7 Relation between the grain size, $d$ and the RIHN. 
速度 $P R$ の間には正の相関が認められ, 平均粒径の大きな岩石 ほど, より大きな穿孔速度が得られる傾向にある。そこで, 平均 粒径 $d$ と RIHN の関係を Fig. 7 に示す。この図から平均粒径の 大きな岩石はRIHNが小さいということが分かる。このことは, 平均粒径が大きいほど破砕されやすく，その結果平均粒径の大き な石灰石ほど大きな穿孔速度が得られることを意味している。破 壊に至る過程としては, 主に粒界破壊と粒内破壊があるが, 平均 粒径が小さい場合, 穿孔によって生じた多数の亀裂は, 主に結晶 粒子間に進展する粒界破壊を引き起こし, 粒内破壊にまで至らな いと考えられる。一方, 平均粒径が大きい場合, 粒界破壊に加え て結晶粒子内に亀裂が進展することにより生ずる粒内破壊も引き 起こしていると思われる。

次に, 粒径の相異に依存した破壊形態の穿孔速度に及ぼす影響 について検討する。穿孔破碎は, 穿孔ビットに押し付け力を与え, 穿孔対象岩石中の結晶粒子間の結合力を破断し, 新しい表面が形 成されることにより生ずるものである。ここで，破砕に費やされ たエネルギーが同じならば，岩石中に同程度の新表面積が形成さ れると仮定する。このような場合, 主に粒界破壊が卓越した平均 粒径の小さい岩石の穿孔では, 平均粒径程度の破砕産物以上のも のは生じないと考えられる。一方, 平均粒径が大きい場合には, 粒界破壊に粒内破壊も伴うため, 同程度の新表面積が形成されて いても破砕産物の体積は平均粒径が大きい場合の方が大きいと思 われる。したがって, 平均粒径の大きな岩石ほど大きな穿孔速度 が得られたと考える。

以上のことから, 穿孔の対象となる石灰石の破砕性は平均粒径 に大きく影響され，結果的に穿孔能率は平均粒径に影響されるこ とが分かる。また, 石灰石のようにほぼ同じ組成をむつ岩石では, $R I H N$ をむって平均粒径の違いを推定することも可能であると 考える。

\section{4. 穿孔機の適用性の評価}

\section{$4 \cdot 1$ 穿孔機の使用状況}

穿孔機種選定時の穿孔機の適用性の評価には, 生産コストを左 右する起砕量や起碎産物の粒度等を考慮した発破規格をはじめ, 機種特性の長短所についても十分検討, 把握する必要がある。そ こで, 代表的な石灰石鉱山の実績デー夕を集計, 整理し, 機種選 定時の指針のひとつとなる穿孔機の使用状況について検討した。

いま述べたように, 穿孔機の適用性や生産性等を考慮する場合 には, 穿孔速度と発破による石灰石の破砕量を併せて議論すべき である。そこでまず, 穿孔ビット径 $B d$ と起砕能率 $D P_{g}$ の関係 をFig. 8 に示す。ただし, 起砕能率は前掲(5)式で示されるよう に穿孔速度之破砕量を考慮したパラメータであり, 単位時間当た りの破砕量を意味している。また，これらの穿孔ビットにはボ夕 ンビットが用いられている。この図より, ビット径が増大するに つれて起砕能率が増大する傾向にある。ビット径の大小は各採掘 現場の発破規格により定められているが, 使用されるビット径に より穿孔機の適用性や生産性が大きく影響されることは明らかで ある。次に機種別にみると, ロータリドリルが用られている現場 で最も高い起砕能率が得られている。Fig.9にはビット径 $B d$ と 純穿孔速度に対する総穿孔速度の割合 $P R_{g} / P R_{n}$ の関係を示す。 この図より, ロッドの継ぎ替え等のロスが小さくて斉むように改 善された大口径のロータリドリルは, 純穿孔速度に対する総穿孔 速度の割合が大きくなっていることが分かる。

以上のことから, 大口径のロータリドリルによるベンチ発破採 掘では高い生産性が得られるため, 石灰石の穿孔には最適である と思われる。また,この機種は孔壁の仕上がり状態が他に比べて

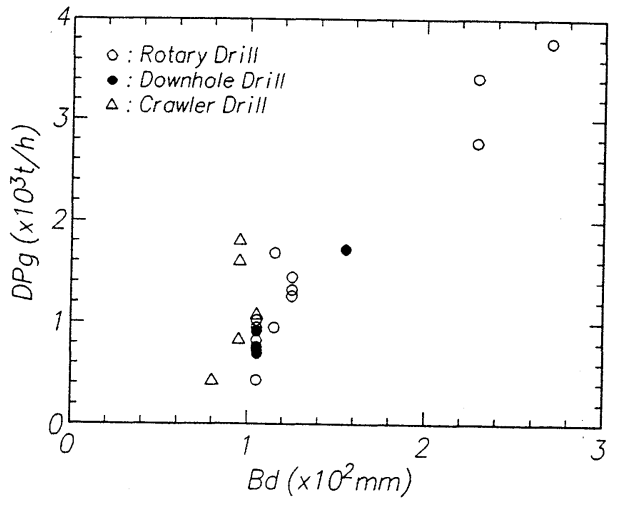

Fig. 8 Relation between the diameter of the drilling bit, $B d$ and the characteristics of fragmentation after blasting, $D P_{g}$.

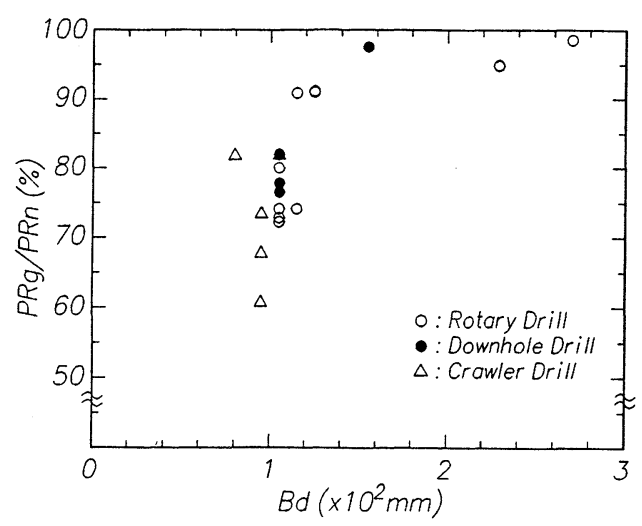

Fig. 9 Relation between the diameter of the drilling bit, $B d$ and the ratio of the gross drilling rate to the net drilling rate,
$P R_{g} / P R_{n}$.

良好であり, 騒音あ比較的小さいという長所あある。しかし, 周 辺環境に制約がある場合や, 生産品のサイズ等により, それに応 じた発破規格が計画されるため, 穿孔径や使用機種が制限される。 また, 一般的に生産性の高いロータリドリルはビットの摩耗が他 の機種に比べて大きいという報告があり ${ }^{5)}$, このような場合には ダウンザホールドリルやクローラドリルを補助的に用いた生産が 必要である。したがって, 使用する穿孔機の穿孔能率や発破規格, 孔壁の仕上がり状態, 破砕産物のサイズなど, 多角的に考慮した 穿孔機の機種選択は非常に重要な課題であることが分かる。

\section{$4 \cdot 2$ 穿孔速度および能率の予測}

前節の結果を踏まえて, 穿孔能率の予测式の導出についての検 討を行う。先に述べたように, 精度の高い穿孔能率の予測式や穿 孔機の機種の選定についての汎用的な指針は未だ十分に得られて いない。これは穿孔能率の予測や機種の選定パラメータとして, 岩盤の基本的な強度特性值, すなわち穿孔対象岩石の一軸圧縮強 度のみを用いてきたことに起因していると考えられる。この強度 特性値は, 一定の形状に整形した供試体に軸方向にのみ圧縮力を 作用させ，その供試体が支持し得る最大の応力であって定義され るあのであり, 岩石の破砕性を十分に記述するあのとはなってい ない。これに代わるあのとして, 筆者らはこれまで掘削能率の予 測や機種の選定についての検討の際には RIHN を利用してき $た^{6)}$ 。また, 詳細は既報 6 に譲るが, RIHNが穿孔性をあ定量的 に評価できるインデックスとなり得ることをむ示した。そこで $R I H N$ を用いた簡便な穿孔速度の評価法として, Rabia ${ }^{7)}$ が 提案した次のような経験式をもとに穿孔速度予測式の導出を試み る。 


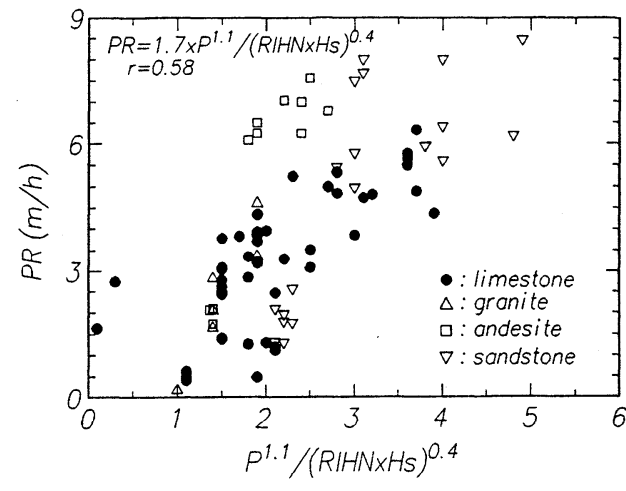

Fig. 10 Relation between the drilling rate and the parameter which obtained from the regression analysis.

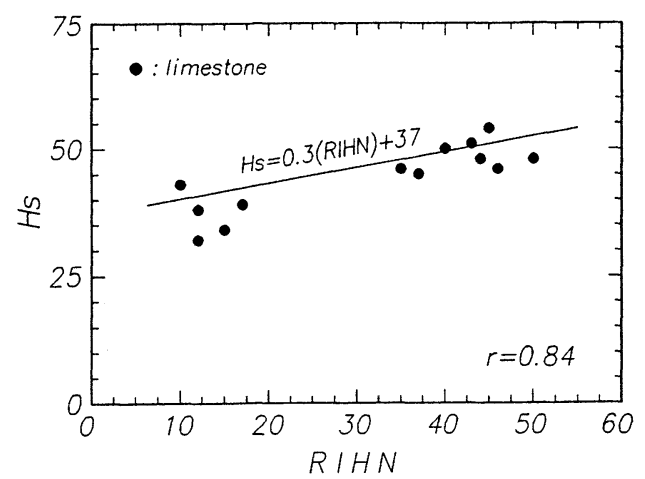

Fig. 11 Relation between the RIHN and the Shore hardness, $H_{s}$.

$$
P R=C \frac{P^{a}}{\left(R I H N \times H_{s}\right)^{b}}
$$

ここで， $C, a$ および $b$ は使用する穿孔機や実験条件により決ま る実験定数であり，P， $H_{s}$ はそれぞれ作動ゲージ圧とショア硬 度数である。彼らは, 穿孔速度や穿孔能率の予測あるいは穿孔機 種の選定には, 機械特性パラメータとして作動ゲージ圧を採用し ているが,ここでは作動ゲージ圧の代わりに穿孔試験により得ら れる押し付け力を用いた。

先に述べたように, 穿孔能率は押し付け力と破砕性に影響を及 ぼされることが確認された。そこで，これらの結果をあとに(6) 式に従い穿孔速度, 押し付け力, RIHN およびショア硬度数を 用いて回帰分析を行った結果得られる関係を Fig. 10 に示す。こ の図に見られるように，かなりのバラッキが認められる。また， 前掲(6)式にはショア硬度数が含まれているが, これは穿孔の際, 岩石表面の硬度が大きいほどより大きな押し付け力を必要とし, 押し付け力の不足による穿孔能率の低下を考慮したことによると 思われる。ここで，RIHN とショア硬度数の関係を見ると Fig. 11 に示すようであり, 両者の間にはかなり強い正の相関が認め られ, RIHN とショア硬度数は互いに依存していると考えられ る。したがって, 岩石表面の硬度の押し付け力への影響は RIHNによって評価することができるため，(6)式からショア硬 度数を削除してあ穿孔速度の予測には影響しないと思われる。

これらの結果をむとに，(6)式からショア硬度数を削除して重 回帰分析を行った結果を Fig. 12 に示す。この図より重回帰分析 を行って得られた予測式は, 相関係数 $r$ が 0.57 とあまり良くな い。そこで，穿孔特性曲線を模式的に Fig. 13 のように表すと， 穿孔特性曲線は,

(1) grinding phase $(\mathrm{A}-\mathrm{B}$ 間)

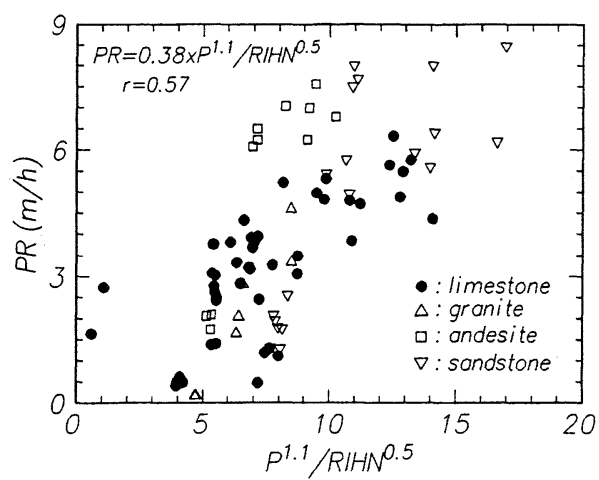

Fig. 12 Relation between the drilling rate and the parameter which obtained from the regression analysis (the Shore hardness is deleted from the equation (6)).

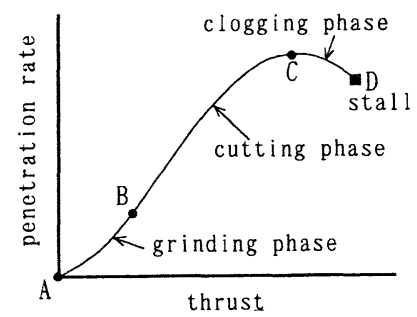

Fig. 13 Schematic curve of the drilling characteristics.

(2) cutting phase $(\mathrm{B}-\mathrm{C}$ 間)

(3) clogging phase $(\mathrm{C}-\mathrm{D}$ 間)

の 3 段階に分けられる5)。ここで，(1)は押し付け力不足による穿 孔ビットの摩耗が著しい段階, (2)は適切な押し付け力により効果 的な穿孔が行われる段階, (3)は繰り粉の除去能力の限界に達し穿 孔作業の停止に至る段階である。このように，押し付け力の与え 方により岩石の破研に費やされるエネルギーの割合が大きく異な るため, (1)〜 (3)のすべての穿孔結果を用いた Fig. 12 の相関性が あまり良くなかったと考える。したがって，押し付け力を穿孔速 度の予測パラメータとして用いる場合には, 上述の点を十分留意 する必要がある。すなわち, 押し付け力を予測パラメータに利用 する場合, 穿孔対象岩石の穿孔特性を明確に表現する值を選択す るべきである。この観点から，与えたエネルギーが最も効果的に 破砕に費やされる段階，すなわち Fig.13 の(2)の段階のデー夕を 予測パラメータとして用いることにする。Fig. 14 に，穿孔試験 結果から図中の(2)のデータのみを用いて再度重回帰分析を行った

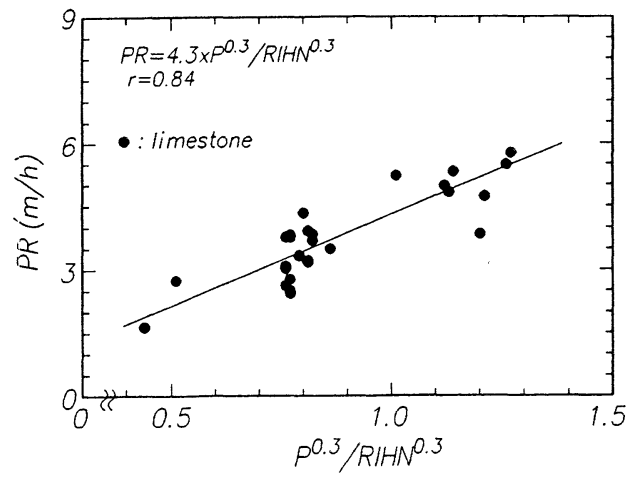

Fig. 14 Relation between the drilling rate and the parameter which obtained from the regression analysis (where the thrusts are used the data in cutting phase). 
結果を示す。この図よりデー夕選択の効果が顕著に現れ，かなり 強い正の相関が認められることが分かる。したがって，穿孔速度 の予測式は次式となる。

$$
P R=4.3\left(\frac{P}{R I H N}\right)^{0.3}
$$

ここで，室内試験に用いた穿孔機はクローラドリルの機構と類似 しており，また打撃式穿孔機之回転式穿孔機あるいは回転一打撃 式穿孔機の穿孔速度は互いに強い正の相関があることが示されて いるため8), 上式をクローラドリル以外の他の機種に対しても十 分利用できると思われる。なお，(7)式は室内穿孔試験により得 られた結果であり，これの実現場への適用の際には，使用穿孔機 のスケーリングファクタについての検討を要する。また，実際の 穿孔作業では岩盤の亀裂状態や貫入岩の影響について屯考虑しな ければならない9。今回は穿孔速度予測式の現場への適用につい ての検討は行っていないが，現場に適用する場合，これらの影響 係数を(7)式に加味する必要があると思われる。

以上の結果より，穿孔速度や穿孔能率の予測には，まず実際の 穿孔機種の破砕機構を考慮した室内試験により, 各種機械パラメー 夕が穿孔破砕特性によ゙のような影響を及ぼしているかについて把 握し, 得られた結果より現場試験におけるパラメー夕を選択する。 そして, 上述の手法により予測式を導出し, 穿孔速度や能率を予 測すれば良いと考える。ただし, 穿孔能率を論ずる場合, 使用す る機種の穿孔特性や穿孔ビットの摩耗量, 純穿孔能率を向上させ るために必要な作業環境の改善方法等についても考慮する必要が ある。

最後に，石灰石鉱山における穿孔機の機種選定の指針について 述べる。これまで, 穿孔速度や能率の予測には, 機械パラメー夕 と岩盤パラメータが含まれた（6)式により可能であることを述べ てきた。この方法は, 比較的簡便であり測定デー夕を増やすこと により現場に十分利用できるものである。そこで, 前述の手法に より得られる予測式をむとに穿孔機の機種選定の指針について述 べる。Fig. 15 に以下の 3 つのステップからなる機種選定の指針 を示す。

ステップ 1 : 穿孔能率に影響を及ぼす要因の検討

ステップ $2:$ 穿孔能率予測式の導出

ステップ 3 : 仮想起砕量とコストの比較による最適機種の選定

まず，ステップ1では，現場試験により各種機械パラメー夕お よび岩盤特性パラメー夕が穿孔特性によ゙のような影響を及ぼして いるかについて把握し, 穿孔速度の予測に用いるパラメータを選

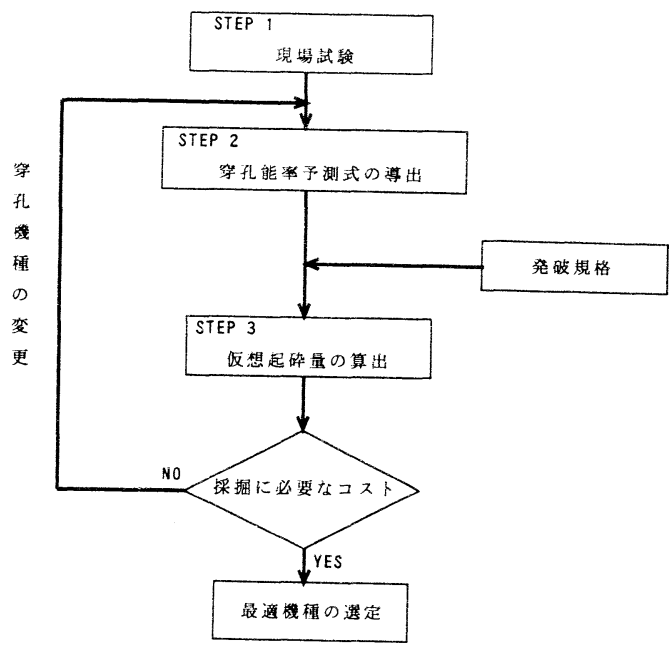

Fig. 15 Flowchart of the selecting method of the drilling machine.
択する。すなわち，岩石の破砕特性值である RIHN や岩盤の亀 裂密度等と穿孔速度の関係, 穿孔機の作動ゲージ圧と押し付け力 の関係等を検討する。次に，ステップ 2 ではステップ1で得られ た結果をもとに上述の手法により予測式を導出し，穿孔能率の予 測を行う。そして, 最終段階であるステップ 3 では, 導出した予 測式より得られる仮想の穿孔実績と採用されている発破規格より, 仮想の起砕量を算出し，これ之計画において要求される採掘量を 比較する。この過程を採用想定機種毎に繰り返し, 要求される採 掘量を満足するのみでなく，コスト的にも優れるものが最適な機 種となる。

これまで，穿孔機種の選定についての汎用的な指針が十分得ら れてなかった一因として, 前述した予測パラメー夕の問題以外に 穿孔機種毎の詳細な実績デー夕の収集に費やされるコストや時間 の問題が挙げられる。しかし, 穿孔中に計測した情報をリアル夕 イムで採取する技術10)等が今後ますます発達していく可能性が 高いことから，将来的には穿孔機種選定の系統的な指針をあ確立 できると思われ，今後む検討していく予定である。

\section{5. 結}

本論文は，石灰石鉱山における穿孔機の適用性を評価するため に，まず石灰石の破砕性, 平均粒径等が石灰石の穿孔性によ゙のよ うに影響を及ぼすかについて検討し, 次に穿孔速度や能率の予測 式の導出方法, 穿孔機の適用性の評価指針について検討した。

その結果，まず最適な押し付け力を知ることが良い穿孔能率を 得る上で重要であることを明らかにした。また，平均粒径も穿孔 能率に大きく影響を及ぼし, 平均粒径が大きいほど, 大きな穿孔 速度が得られることが分かった。

次に, 現在行われている穿孔・発破工法で使用される穿孔機の 適用性判断の指針の構築の一歩として, 室内試験結果から穿孔能 率の予測式について検討した。その結果, Rabia らの実験式を あとにした穿孔速度予測式と起砕能率を検討することにより, 穿 孔機の適用性や生産性を評価できる可能性があることを明らかに した。

謝辞石灰石および現場実績データ採取に当たっては石灰石 鉱山関係各位に, 穿孔試験を行うに当たっては三菱マテリアル (株)中央研究所の関係各位に多大なるご理解とご協力を賜ったこ とに深甚なる感謝の意を表する。また, 本研究に当たり, 当資源 工学科の一ノ瀬政友博士にご助言, ご検討をいただいたことに謝 意を表する。さらに, 本研究の一部は, 石灰石鉱業協会研究奖励 金によって行ったことを付記し，感謝の意を表する。

$$
\text { 引用文献 }
$$

1）金子勝比古・西田 稔・稲葉 力・山内 清：資源之素材，Vol, 107, p. 959964, (1991)

2）本田裕夫・萩森健治・古川浩平・中川浩二：土木学会論文集 $379 / \mathrm{IV}$ - 6, p. 247256, (1987)

3）島田英樹・松井紀久男・一/瀬政友：資源之素材，Vol. 108, p. 402-406, (1992)

4) Matsui, K. and Shimada, H. : Proc. of 2nd Symposium on Mine Mechanization and Automation, p. 265-270, (1993)

5) Clark, G. B.: Principles of Rock Fragmentation, p. 154-217, John Wiley and Sons, (1987)

6）島田英樹・松井紀久男：資源之素材，Vol. 110, p. 499-503, (1994)

7) Rabia, H. and Brook, N. : Int. J. Rock Mech. Min. Sci. and Geomech. Abstr., 18 , p. $211-219,(1981)$

8) Howarth, D. F. and Adamson, W. H. : Int. J. Rock Mech. Min. Sci. and Geomech. Abstr., 25, p. 25-33, (1988)

9）室 達朗・深川良一・渡邊公浩：第 19 回岩盤力学に関するシンポジゥム講演論 文集, p. 471 -475, (1987)

10）例えば，唐澤廣和・大野哲二・三澤茂夫：資㟲・素材学会平成 6 年度春季大会 講演要旨集, p. $25-26,(1994)$ 